\title{
Continuing issues with Lead: Recent Advances in Detection
}

\author{
Kristine Deibler and Partha Basu \\ Department of Chemistry and Biochemistry, Duquesne University, 600 Forbes Ave., Pittsburgh, \\ PA 15282 (USA), Fax: (+1) 412-396-5683 \\ Partha Basu: basu@duq.edu
}

\begin{abstract}
In the past $\mathrm{Pb}^{2+}$ has been used in many industries, including gasoline, piping, toys, paints, and more. The use of lead has led to a natural increase of lead concentration in the environment especially in air and water. According to the U.S. CDC "no level of lead in blood is considered safe." Exposure to very low amounts of lead can cause several health complications including developmental and neurological disorders. Over the past several years an emphasis has been placed in developing systems that can detect lead at a very low concentration. A great deal of work has been accomplished in the development of $\mathrm{Pb}^{2+}$ sensors that can not only detect but also quantify the amount and in some cases in the presence of other metal ions. Herein, we describe current regulations, mode of exposure and recent development of sensing techniques.
\end{abstract}

\section{Keywords}

Lead Poisoning; Heavy Metal; Metal Ion Detection; Heavy Metal Contamination; Fluorescent Sensors

\section{Introduction}

Lead has no known natural biological role in humans. It is a persistent environmental contaminant and has been viewed as a common environmental health concern. Lead is a strong chalcophile, found naturally in the environment mainly in ores of zinc, silver, and copper. The major sources of lead are in galena $(\mathrm{PbS})$, cerrussite $\left(\mathrm{PbCO}_{3}\right)$, and anglesite $\left(\mathrm{PbSO}_{4}\right)$ deposits. ${ }^{1}$ The primary cause of lead contaminated soils, air, and water systems are due to anthropogenic activities such as burning leaded gasoline, use of lead solder, lead piping, and lead based paints. ${ }^{1,2}$ The natural levels of lead in surface and ground waters is very low $(<5 \mathrm{ppb})$ but in some areas higher than $1000 \mathrm{ppb}$ lead have been found in both water and soil. ${ }^{2}$

There has been reports of mass lead intoxication in Senegal and Nigeria, which caused significant lose in life and developmental issues with children. ${ }^{3,4}$ This lead-cycle initiated by anthropogenic activities is more extensive than the natural lead-cycle, causing lead pollution a worldwide issue. The median BLLs in children under age 6 fell from about $15-18 \mu \mathrm{g} / \mathrm{dL}$ in 1970 to $2-3 \mu \mathrm{g} / \mathrm{dL}$ in 1994 . However, more than 250,000 children of the age $1-5$ years have 
BLLs above the Center for Disease Control (CDC's) recommend action limit of $5 \mu \mathrm{g} / \mathrm{dL} .{ }^{5,6}$ Even at extremely low levels, lead has been linked with a range of health effects including behavioral problems and learning disabilities. ${ }^{7-13}$ Lead enters the body through a multitude of pathways and understanding these pathways, the process of storage and transport, and localization in cells can help better evaluate the biological effects of lead.

The environmental concerns and associated health effects at a very low levels of lead means tools to detect and quantify lead must be operable at low concentrations. Sensitive, selective, and simple methods of detection are crucial in not only preventing contamination but for better understanding of biological pathways of lead. Several reviews have focused on the sensing techniques of different groups of metals (e.g., heavy metal, alkali metal) or focus on a specific type of sensing (e.g. DNAzymes, nanoparticles, fluorescent molecules, etc). ${ }^{14-17}$

\section{Lead Exposure}

In general, exposure to toxic metals may occur through food, medications, the environment i.e., water and air, or during occupational and/or recreational activities. In terms of environmental contamination, levels of pollutants are usually small in waters but they can be higher in certain zones due to industrial and domestic waste discharge. ${ }^{18}$ Aquatic plants and animals, in particular some mollusks, can accumulate high levels of toxic elements such as arsenic and cadmium providing a vehicle to introduce toxic metals into the food chain. ${ }^{18} \mathrm{In}$ Europe, it has been reported that 17 species of birds of prey have had lead poisoning. ${ }^{19}$ Some of these birds include the White-tailed Eagle and the endangered Spanish Imperial Eagle. ${ }^{19}$ Heavy metals, including lead, are absorbed through the roots and leaves of plants. ${ }^{20}$ This can then interfere with the levels of antioxidants in plants, and reduce the nutritive value of the produce ${ }^{20}$ Individuals are exposed to lead and its harmful effects through two main routes: from air and water. Lead containing particles or aerosols generated from leadbased paints, gasoline and industrial manufacturing serve as the primary route to aerial lead exposure. The second route is from water, dispensed from lead based pipes. ${ }^{21-26} \mathrm{In}$ adults, the deleterious effects of lead may be reversed through chelation therapy, but the effect on children is more permanent.

Young children are particularly sensitive to exposure to lead due to their developmental properties and hand-to-mouth behavior. ${ }^{27}$ Young children are more susceptible to the hazardous health effects of lead exposure because they absorb more of the ingested lead. ${ }^{28}$ Lead has been found in high concentrations in children's products, especially toys and candy. ${ }^{29}$ Indeed, a widespread problem has been reported with high metal contamination in toys and certain jewelry as children ingest $\mathrm{Pb}$-contaminated products. One of the main sources of $\mathrm{Pb}^{2+}$ in jewelry items is thought to be the use of recycled electronic wastes and lead battery. ${ }^{30,31}$ In the past few years millions of toys have been recalled because of chemical safety hazards, for violating lead paint standard. ${ }^{32,33}$ It has been reported that metal leaching from several plastics, including children's toys, has toxic effects on fish. ${ }^{34}$ In addition to $\mathrm{Pb}, \mathrm{BaCd}$, and $\mathrm{Cr}$ have been found in baby toys. ${ }^{35}$ Weidenhamer and Clement examined 39 jewelry items and found they contain $90 \%$ or more lead by weight. ${ }^{36}$ Children living in urban areas typically exhibit elevated blood lead levels (BLLs) along with many 
major cities having recent spikes in the lead concentration of their water system due to disinfectant switches. ${ }^{26,37-39}$

Another current issue with lead exposure accompanies changes in the water systems disinfectants utilized. Figure 1 shows two different common approaches for disinfecting waters from microbial species. Traditionally, chlorine has been used in the drinking water system as a disinfectant, but recent concerns of toxic disinfectant by-products has lead to the use of a substitute, chloramine. ${ }^{38}$ In addition to forming carcinogenic nitrosamines, the switch from chlorine to chloramine has also been connected to elevated levels of lead in drinking water. ${ }^{40}$ Higher levels of $\mathrm{Pb}^{2+}$ in drinking water has lead to an elevated level of lead in human blood samples in Washington DC, Portland OR, Providence RI, and other cities. ${ }^{41,42}$ Edwards and colleagues reported a significant increase in BLLs in Washington D.C. ${ }^{42}$ The use of chlorine typically inhibits the leaching of lead from pipes as it oxidizes $\mathrm{Pb}^{2+}$ to $\mathrm{Pb}^{4+}$ and creates a coating of slightly insoluble lead oxide $\left(\mathrm{PbO}_{2}\right)$. Chloramine is a weaker oxidant than chlorine, which does not produce such protective coatings, and this in turn releases more $\mathrm{Pb}^{2+}$ into the drinking water. ${ }^{6}$

\section{Maximum Contamination Level and Lead Toxicity}

Lead is a toxic metal that has been in use for many decades as discussed above, and different regulatory agencies have set a limit of maximum contamination level (MCL) for lead.

However, the limits vary from agency to agency as well as the material they regulate (Table 1). According to the U.S. CDC a 100-190 ppb BLL poses a potential threat and that diagnostic testing is strongly encouraged. ${ }^{5}$ In 2010 the EPA set the maximum contaminant level goal (MCLG) for lead to zero ppb and the action level at $15 \mathrm{ppb}$, in drinking waters. ${ }^{43}$ The U.S. Food and Drug Administration (FDA) has set maximum level of $0.1 \mathrm{ppm}$ for lead in candy. ${ }^{44}$ Additionally, the Consumer Product Safety Commission (CPSC) has recently lowered the limit of lead in children's product to $100 \mathrm{ppm} .{ }^{45}$ This trend of lowering the maximum limit of lead in many consumer products is in response to the increasing recognition of the threat that lead poses. A low level exposure to lead can cause neurological, reproductive, cardiovascular, and developmental disorders. ${ }^{7-13}$

Lead is known to bioaccumulate in bones for up to 20 years and is not hazardous to human health unless it is released, this can occur when the bones experience turnover and remodeling by osteon activity. ${ }^{46,47}$ Lead is a likely target of calcium- and zinc-binding proteins ( $\mathrm{C} 2 \mathrm{~A}$ domain of synaptotagmin I and cysteine-rich zinc finger proteins) that control cell signaling and gene expression, respectively, but the molecular and cellular mechanisms of lead toxicity remain an open question. ${ }^{48-52}$ Lead can also be taken up by the cell by copper and zinc transporters and have been observed to cause both oxidative stress and DNA damage. ${ }^{53,54}$ Lead is also known to interfere with the biosynthesis of heme. ${ }^{55}$

Bradman et. al. reported that iron deficiency increases BLLs perhaps due to an increase in absorption and retention of lead. ${ }^{56}$ In addition, $\mathrm{Pb}^{2+}$ may bind in vacant $\mathrm{Fe}^{2+}$ sites in the hematopoietic system, resulting in reduced lead excretion. ${ }^{56}$ Hopkins et. al. have demonstrated a close association between iron metabolism genes with lead exposure in children. As mentioned, iron deficiency has been implicated with an increased absorption and deposition of lead. However, iron supplement given to a control group did not change 
the BLL, and children with genetic variants may be more prone to the lead poisoning. ${ }^{57}$ Interest in explaining these pathways, as well as public concerns over toxic lead exposure, provides a need for devising new ways to track $\mathrm{Pb}^{2+}$ in natural samples.

\section{Current Method of Detection}

Metal ions enters into the cells through several ways and understanding these pathways of metal incorporation, the process of their storage and transport, and localization in cells can help for the better understand normal functioning as well as the diseased states. These methods with their detection limits are listed in table 2.

\section{Techniques Approved by Regulatory Agencies}

The United States EPA approved methods for lead detection are inductively coupled plasma mass spectrometry (ICP-MS) ${ }^{58}$ with a detection limit of $0.6 \mathrm{ppb}$, inductively coupled plasma atomic emission spectrometry (ICP-AES) ${ }^{59}$ with a detection limit of $42 \mathrm{ppb}$, and graphite furnace atomic absorption spectroscopy (GFAAS) ${ }^{60}$ with a detection limit of $0.7 \mathrm{ppb}$. The detection limits and linear working ranges are dependent on the sample matrix, instrumentation, and selected operating conditions. These methods provide means to determine dissolved lead in ground waters, surface waters, drinking water, wastewaters, sludges, and soil samples. ${ }^{58-60}$ There are four natural isotopes of lead and in ICP-MS three isotopes $\left({ }^{206} \mathrm{~Pb},{ }^{207} \mathrm{~Pb}\right.$, and ${ }^{208} \mathrm{~Pb}$ ) are typically monitored, however the method suffers from interferences including isobaric elemental interferences, abundance sensitivity, isobaric polyatomic ion interferences, and physical interferences. Another EPA approved method, ICP-AES, experiences interferences from $\mathrm{Co}, \mathrm{Al}, \mathrm{Ce}, \mathrm{Cu}, \mathrm{Ni}, \mathrm{Ti}$, and $\mathrm{Fe}$ at $100 \mathrm{mg} / \mathrm{L}(100$ $\mathrm{ppm})$ at the recommended wavelength of $220.353 \mathrm{~nm} .{ }^{59}$ Similar to ICP-MS, one can perform direct analysis of samples with GFAAS. Although GFAAS is a reliable and sensitive method, the necessity of additives and modifiers is considered to be a disadvantage. If the sample preparation involves digestion with $\mathrm{HCl}$, for example, it can influence the sensitivity for lead detection. This effect can be corrected up to $10 \%$ with the addition of $\mathrm{Pd} / \mathrm{Mg} / \mathrm{H}_{2}$ as a modifier. ${ }^{60}$ Though the FDA and CPSC have significantly higher lead limits, they employ the analysis similar to the EPA. ${ }^{61,62}$

These methods usually require small sample size and sensitive, they are instrument intensive, non-portable, and require trained technicians. Also, the sample preparation of specific metal ions may require a long digestion process. First, the composite sample must be blended with water and/or nitric acid, and predigestion is often required for suspended samples. Generally, the microwave digestion is followed by analysis with GFAAS, ICPAES, and ICP-MS. Overall, the most favorable EPA approved method of analysis for lead in an environmental water sample is ICP-MS. ${ }^{58}$ ICP-MS analysis often serves as the simplest sample preparation, with least interference, and lowest detection limit. For these reasons, ICP-MS has been viewed as a gold standard for other methods, including those described herein. These methods that have been approved by the regulatory agencies have a major limitation as they cannot be easily used to monitor the distribution of metal ions in real time. Thus, a simple, rapid, inexpensive, minimal sample handling, selective, and sensitive method that permits real time detection of metal ions is of interest. 


\section{Electrochemical Techniques}

A traditional method of metal ion detection is the application of electrochemical properties including anodic stripping voltammetry (ASV), cathodic stripping voltammetry (CSV), and adsorptive stripping voltammetry (AdSV). ${ }^{63-65}$ These methods can be used determine metal ion concentrations in water to sub-parts-per-billion levels. They usually incorporate three electrodes, a working, auxiliary, and reference electrodes. The analytical species is reduced onto the working electrode and is then oxidized, "stripped", back into the electrolyte solution. ${ }^{66}$ The stripping current due to oxidation of each analyte is proportional to the concentration of that analyte on or in the electrode and thus, in the solution in question. ${ }^{66}$ Mercury film electrodes (MFE) and the hanging mercury drop electrode (HMDE) have been traditionally used for ASV because of the negative potential range of mercury but due to the potential health hazards of mercury alternative electrodes have been sought. ${ }^{67} \mathrm{~A}$ bismuthfilm electrode (BFE) has been successfully used to determine $\mathrm{Zn}, \mathrm{Cd}$, and $\mathrm{Pb}$ at low concentrations. It has mostly been used for the determination of $\mathrm{Pb}$ and $\mathrm{Zn}$ in tap water and in human hair. ${ }^{63} \mathrm{ASV}$ has also been frequently used to determine BLLs. ${ }^{57,63,68}$

A recent development in electrochemical detection of $\mathrm{Pb}^{2+}$ utilizes the traditional bismuth electrode but also carbon composite, G-quadruplex, phenanthroline, and DNA combined with $\mathrm{TiO}_{2}$ (Table 2). Quintana et. al. reported a sensitive bismuth-modified screen-printed electrodes (Bi-SPE) for lead detection that avoids the use of toxic mercury containing films. ${ }^{69}$ Stripping voltammetry using SPEs allows the formation of an amalgam that enables the analyte to accumulate on the bismuth film, providing with a higher sensitivity and reproducibility. They carried out in situ or ex situ in the same frame as the European Union project. Ex situ involves putting SPE into the solution containing $\mathrm{Bi}^{3+}$ ions and then a potential to reduce bismuth to $\mathrm{Bi}^{0}$ prior to the addition of the analyte. In situ experiment uses the sample solution containing $\mathrm{Bi}^{3+}$ and thus both analyte and the bismuth are electrochemically deposited on the working electrode. In situ produced a linear working range for lead ion concentration from 0.5 to $100 \mathrm{ppb}$ and a detection limit of $0.15 \mathrm{ppb}$, which proved to be more selective than ex situ measurements. 69

Additionally, Li et. al. used differential pulse voltammetry (DPV) to monitor the G-rich DNA conformational switch, induced by $\mathrm{Pb}^{2+}$, from a random-coil to G-quadruplex (G4) with crystal violet as the G4-binding indicator. ${ }^{70} \mathrm{G}$-quadruplexes are four-stranded DNA structures stabilized by coordination cations and some $\mathrm{K}^{+}$-stabilized G-quadruplexes exhibit superior peroxidase-like activity. This effectively catalyzes a $\mathrm{H}_{2} \mathrm{O}_{2}$-mediated oxidation of 2,2'-azino-bis(3-ethlybenzothiazoline-6-sulfonic acid) diammonium salt (ABTS), which causes a colorimetric and oxidative change. The technique has a detection limit of $82.2 \mathrm{ppt}$, well below the EPA limit. Another electrochemical DNA-based lead sensor has been developed, that involves vertically aligned conductive carbon hybridized $\mathrm{TiO}_{2}$ nanotube (NT) arrays (DNA/C-TiO 2 NTs). ${ }^{71}$ In this case, $\mathrm{TiO}_{2}$ nanotubes were vertically aligned on a Ti substrate by anodic oxidation and then DNA was immobilized onto the substrate. This sensor exhibits a high sensitivity $(2.1 \mathrm{ppt}-32.8 \mathrm{ppb})$, good selectivity $\left(\mathrm{Mn}^{2+}, \mathrm{Mg}^{2+}, \mathrm{K}^{+}\right.$, $\mathrm{Fe}^{2+}, \mathrm{Fe}^{3+}, \mathrm{Co}^{2+}, \mathrm{Cd}^{2+}, \mathrm{Al}^{3+}, \mathrm{Ag}^{+}, \mathrm{Zn}^{2+}, \mathrm{Ca}^{2+}, \mathrm{Ba}^{2+}, \mathrm{Sr}^{2+}$, and $\mathrm{Hg}^{2+}$, and a wide $\mathrm{pH}$ range. The superior characteristics for lead sensing were attributed to the immobilization of abundant target biomolecules, DNA, and the enhanced bioelectrical activity. The 
controllable carbon hybridized of the $\mathrm{TiO}_{2}$ NTs increases the conductivity of the electrode, while retaining the tubular structure, biocompatibility and hydrophilicity. ${ }^{71}$ The electrode can then be regenerated for multiple uses including numerous environmental sites.

Bouw and colleagues reported a low cost electrochemical sensor based on clay modified by 1,10-phenanthroline within montmorillonite (MMT). ${ }^{72} \mathrm{~Pb}^{2+}$ is sensed by a carbon paste electrode (CPE) by adsorptive stripping voltammetry through the exchange of saturated sodium ions by $\mathrm{Pb}^{2+}$. The low cost materials, ease of preparation and use, and low detection limit (82.2 ppt) make this method an attractive one for testing environmental samples, however, the approach suffers from a 70\% reduction in $\mathrm{Pb}^{2+}$ signal in the presence of $\mathrm{Hg}^{2+}{ }^{2}{ }^{72}$ Another low cost approach, developed by Abbaspour et. al., uses reusable and disposable carbon composite PVC-based membranes, where a Pt wire was coated with phenyl hydrazone derivative-carbon composite in PVC membrane. ${ }^{73}$ The membrane sensors have a fast response time and can be reused for up to 70 days, and is fairly sensitive with a detection limit of $65.8 \mathrm{ppb}$. The new developments in reusable, disposable, and affordable electrochemical sensors has been exciting, however, there is a room for improvement in their selectivity as well as sensitivity. Also, these electrochemical techniques do not provide any spatial information, which is of interest to better understand the cellular distribution of lead.

\section{Nanoparticles}

Gold nanoparticles have been used in sensors because of their extremely high extinction coefficient in the visible wavelength range. Typically, even at nanomolar concentrations, the color change of the particles can be observed by the naked eye. Recently, Yang et. al. reported a bromide capped gold nanoparticles for sensing lead. ${ }^{74}$ In this case, $\mathrm{Pb}^{2+}$ reacts with bromide ions to form $\mathrm{PbBr}_{2}$ on the surface of the gold nanoparticles that exhibits luminescence by absorbing in the UV region $(300 \mathrm{~nm})$ with visible emission $(600 \mathrm{~nm})$. With an increase in $\mathrm{Pb}^{2+}$ concentration the color of the particles changes from red to light blue and even become colorless which can be visualized with naked eyes. Alkali metals cause no spectral changes. However, alkaline earth and heavy metals show small changes, and even with 4 to 5 equivalents of these ions, $\mathrm{Pb}^{2+}$ has been detected. ${ }^{74}$ In this case, no rigorous synthetic or biological procedures to be adopted; the sensor is water soluble, and has the very desirable visible region optical properties but the detection limit is above EPA limit. Wang and Guo reported a new nanoparticle based lead sensor that utilizes fluorescence resonance energy transfer (FRET) for $\mathrm{Pb}^{2+}$ detection. ${ }^{75}$ It comprised of a positively charged CdTe-QDs capped with cystamine (CA-CdTe-QD) and negatively charged AuNPs capped with 11-mercaptoundecanoic acid (MUA-AuNPs). ${ }^{75}$ The lead assay utilizes FRET efficiency of the positively charged quantum dots (QDs) and the negatively charged gold nanoparticles (AuNPs) which in the presence of $\mathrm{Pb}^{2+}$ the electrostatic interaction of inhibited. They are water soluble and biocompatible, easy to operate, and little interference from physiological metal ions but the working range of this sensor is parts per million although the detection can be as low as $30 \mathrm{ppb}$. $\mathrm{Fe}^{3+}$ and $\mathrm{Ag}^{+}$ions interfere with $\mathrm{Pb}^{2+}$ detection, which can be improved in this exciting sensor. 


\section{DNAzymes}

DNAzymes were first reported in 1994 showing approximately an 100-fold increase in a lead ion dependent cleavage process of a double stranded DNA that is linked with a flurophore or a chromophore and a quencher, and when the double strand is cleaved a fluorescence or a difference in absorption is observed. ${ }^{76}$ In general, DNAzyme-based $\mathrm{Pb}^{2+}$ sensors are composed of an enzyme and substrate strand and the addition of $\mathrm{Pb}^{2+}$ enables the DNAzyme to cleave its substrate. Several lead-specific DNAzyme were built on the 817 base pair that are capable of catalyzing a phosphodiester bond cleavage in the presence of $\mathrm{Pb}^{2+}$. In 2003 Liu introduced a DNAzyme adhered to gold nanoparticles that allows tuning of the detection level over several orders of magnitude. ${ }^{77}$ In this case, the $3^{\prime}$ strand of a DNA is binds to gold nanoparticles (diameter, $13 \mathrm{~nm}$ ), which causes aggregation of the nanoparticle exhibiting a blue color. In the presence of $\mathrm{Pb}^{2+}$, the complementary $5^{\prime}$ strand that can recognize the $\mathrm{Pb}^{2+}$ catalyzes a hydrolytic cleavage preventing the formation of the $\mathrm{NP}$ aggregates. This results in a red color, sensing the presence of $\mathrm{Pb}^{2+}$. This system allows detection with different dynamic range that are present in various environments in question; for example the EPA has a limit of $15 \mathrm{ppb}$ while the CPSC has limits in the part per million (ppm). Lan et. al. developed a catalytic beacon sensor for $\mathrm{Pb}^{2+}$ based on the first 8-17 DNAzyme that exhibited a higher metal ion selectivity ( 40,000 times), than the previously reported $\mathrm{Pb}^{2+}$ sensors. ${ }^{78}$ Wen developed a "mix-and-detect" fluorescent sensor for $\mathrm{Pb}^{2+}$ ions by using graphine oxide nanoprobes. ${ }^{79}$ Upon addition of $\mathrm{Pb}^{2+}$, the substrate strand was cleaved causing significant quenching of the fluorescence. As the $\mathrm{Pb}^{2+}$ concentration was increased, the fluorescence signal decreased in response to increased cleaved DNAzymes. The dynamic range was tuned to high concentration range by appropriate mixing of enzyme strands. ${ }^{79}$

There has been considerable interest in developing portable and small devices for onsite testing. Chang and colleagues developed a miniaturized DNAzyme in a nanocapillary interconnected microfluidic device. ${ }^{80}$ They combined a lead-specific DNAzyme with a microfabricated device containing a network of microfluidic channels that are fluidically coupled via nanocapillary array interconnect. ${ }^{80}$ This sensor is a unique combination of DNAzyme and microfluid-nanofluid and it has been applied to the determination of lead onsite of an electroplating sludge and reference material. Another small and easy to use device was developed by Wang, a computer-readable DNAzyme $\mathrm{Pb}^{2+}$ assay on disc. ${ }^{81} \mathrm{~A}$ conventional compact disc (CD) was used as the platform for preparing DNAzyme assays and an unmodified optical drive of ordinary computers as the readout device. $\mathrm{Pb}^{2+}$ specific DNAzyme was immobilized on the "transparent side" of a conventional CD-R via mild surface reactions. The concentration of $\mathrm{Pb}^{2+}$ was determined with a diagnostic program that checks the error distribution on the $\mathrm{CD}$. The errors increase linearly over a wide range of concentrations, 2 ppb to 200 ppm. ${ }^{81}$

A recent report in lead specific DNAzymes took advantage of the optical properties of a water-soluble cationic polythiophene (PT) and designed a fluorometric sensing assay for the detection of $\mathrm{Pb}^{2+} .{ }^{82}$ A simple "mix-and-detect" approach enables the detection of $\mathrm{Pb}^{2+}$ within 20 minutes due to the distinguishable optical properties of PT-dsDNA and PTssDNA. The detection was well below the standard EPA at $0.2 \mathrm{ppb}$ but this methods has a 
wide detection range, $2 \mathrm{ppb}$ to $20 \mathrm{ppm}$, enabling diverse functional. ${ }^{82}$ This method avoids modification and separation thus making this simple, sensitive, specific, and cost-effective approach showed great potential in environmental monitoring, waste management and cellular understanding.

\section{DNAzymes and Nanoparticles}

Recent developments have been made using a combination of nanoparticles and DNAzymes. Aside from the optical properties of the gold nanoparticles and DNAzymes, nanoparticles' diameters are related to their disperse state. Thus a change of the disperse state from discrete nanoparticles to aggregates will lead to the increase of their average diameter, which can be monitored by dynamic light scattering (DLS) ${ }^{83,84}$ Miao and colleagues reported a dynamic light scattering sensor for $\mathrm{Pb}^{2+}$, which was constructed with oligonucleotide-modified gold nanoparticles based upon its cleavage property for DNAzyme. ${ }^{85,86}$ The basis for this method was to determine the signal of the average diameter of AuNPs (Figure 3). There are two strands, the enzyme strand and the substrate strand, which can hybridize with each other to form duplex structure DNAzyme. This structure can then be adsorbed on the surface of the AuNPs, preventing them from aggregating in the presence of $\mathrm{NaCl}$. In the presence of $\mathrm{Pb}^{2+}$ the substrate strand of DNAzyme can be cleaved into single strand DNA (ssDNA) fragments and these ssDNA fragments are adsorbed on the surface of the AuNPs to inhibit aggregation in the presence $\mathrm{NaCl}$. Thus, as the concentration of $\mathrm{Pb}^{2+}$ increases the diameter of the aggregates decreases linearly from 2.1 to $61 \mathrm{ppt}$. This method is relatively simple and inexpensive because the DNA is unmodified and not separated.

\section{Organic Molecules}

In the past 20 years fluorescent sensors have been investigated intensely for their potential in real-time monitoring that helps in understanding cellular metal accumulation, trafficking, protein trafficking, small-molecule signaling, organelle distribution, and cell viability, along with the simple, quick, and determining environmental contamination. ${ }^{87-93}$ Fluorescencebased sensors can offer unparalleled sensitivity and thus have garnered significant interest. Traditional methodologies require collection, transportation, occasional pretreatment of the sample, and in many cases, expensive instrumentation operated by trained personnel. ${ }^{28,56-58,94}$ Small molecule sensors are valuable not only as they are cost effective and user-friendly, but also for real time monitoring and garnering special information. ${ }^{94}$ Among the different chemical sensors, fluorescence-based ones present many advantages: fluorescence measurements are very sensitive, it is possible to detect a single molecule, typically low cost, easily performed, versatile, and allow subnanometer spatial resolution. ${ }^{94,95}$ This approach has contributed greatly to explaining the roles of calcium and related s-block metals in biology, ${ }^{95}$ but similar chemical tools for $\mathrm{d}$ - and p-block transition and heavy metals remain somewhat open for study. ${ }^{96}$

Chen et. al. reported a ratiomentric fluorescent sensor based on polypeptide scaffolds equipped with a microenvironment-sensitive fluorophore. ${ }^{96}$ This sensor emits at visible wavelength and has a quantum yield of $0.35 .{ }^{96} \mathrm{He}$ et. al. reported another fluorescent based 
sensor called, Leadfluor-1 (LF1), that shows promise in probing lead in biological samples. ${ }^{97}$ It has a selective turn-on response, visible excitation and emission profile useful for real time monitoring of living cells. ${ }^{97}$ Ranyuk et. al. reported a anthraquinone-based receptor that functions as a colorimetric chemosensor for the selective recognition of lead in water. ${ }^{98}$ This sensor was developed using a systematic approach based on single modification of a one-step available chromogenic macrocyclic backbone, thus this is convenient for the development of selective sensors for different metal ions. ${ }^{98}$ By changing the nature and number of side arms this backbone can be adapted to the nature of the metal of interest. In the presence of 2-3 ppm lead, a distinct change in color can be observed by the naked eye; a detection limit of $21 \mathrm{ppb}$ can be achieved with a spectrophotometer. ${ }^{98}$ Visible detection with the naked eye holds a great prospect for quick detection.

Alongside the development of devices, small organic molecules have been imbedded and immobilized in various substances. A most recent example of this immobilization was reported by Aksuner et. al. ${ }^{99}$ in which a novel triazolo-thiadiazin derivative was immobilized in PVC. The sensor displays a response for $\mathrm{Pb}^{2+}$ over a concentration range of $10 \mathrm{ppb}$ to $78 \mathrm{ppm}$ with the detection limit of $4.5 \mathrm{ppb} .{ }^{99}$ In addition to high reproducibility and reversibility of the fluorescence signal, the sensor also exhibits good selectivity over common metal ions $\left(\mathrm{Na}^{+}, \mathrm{K}^{+}, \mathrm{Ca}^{2+}, \mathrm{Mg}^{2+}, \mathrm{Cu}^{2+}, \mathrm{Co}^{2+}, \mathrm{Ni}^{2+}, \mathrm{Zn}^{2+}, \mathrm{Cd}^{2+}, \mathrm{Mn}^{2+}, \mathrm{Fe}^{3+}\right)$. The membrane is easily prepared, stable, rapid, and is simple. The accuracy of the proposed sensor was confirmed by analyzing standard reference materials of natural water and surface water.

Another small organic sensor was developed in 2009 by Marbella et. al. ${ }^{100}$ It is a unique fluorescent sensor both in structure and binding. Many fluorescent sensors have a flexible framework allowing the coordination to the metal ion, while this molecule has a rigid structure allowing alterations to be imposed without affecting the binding site. Intestingly, only a few metal ion sensors have solely a rigid framework. This sensor, called 'leadglow' (LG) was found to have a 'turn-on,' ratiometric response to $\mathrm{Pb}^{2+}$ in aqueous solution. ${ }^{100}$ The free ligand has an excitation at $415 \mathrm{~nm}$ and an emission at $465 \mathrm{~nm}$. Conversely, the $\mathrm{Pb}^{2+}$ bound ligand has an excitation at $389 \mathrm{~nm}$ and an emission at $423 \mathrm{~nm} .{ }^{100}$ Additionally, LG is able to detect $\mathrm{Pb}^{2+}$ at a wide $\mathrm{pH}$ range (4-10). This allows for the determination of $\mathrm{Pb}^{2+}$ in a variety of samples: slightly acidic, neutral, and basic $\mathrm{pH}$ levels. LG was compared with the EPA approved method. Determination of trace elements in waters and wastes by ICP-MS. By comparing the quantification of $\mathrm{Pb}^{2+}$ in SRM ${ }^{2} 3128$ Lead Standard Solution by both LG and ICP-MS, the two methods were found to be statistically equivalent. LG offers a wide variety of choices from tuning the excitation with the addition of functional groups to the incorporation into a matrix for ease of use. LG shows promise in becoming a simple method to detect $\mathrm{Pb}^{2+}$ in environmental samples.

As environmental and on site testing is of great interest to prevent and monitor lead contamination, advance in small and simple devices has grown. Zhao et. al. developed a micro-fabricated device for detection in water. ${ }^{101}$ It was based on a selective and sensitive fluorescent molecular sensor for $\mathrm{Pb}^{2+}$, Calix-DANS4. ${ }^{101}$ The micro-chip based lead sensor detected by using a configuration in which the sensing molecules are excited by two optical fibers each one connected to a $365 \mathrm{~nm}$ UV LED source, and the light collection is made by 
another optical fiber with a photomulitplier tube. The detection limit is below the EPA limit, permitting onsite testing of rivers and lakes. A recently developed devices used a calixarene bearing three dansyl groups and one long alkyl chain terminated by an alcohol function. ${ }^{102}$ Calix-DANS3-OH was grafted on the wall of a PDMS microfluidic device. It has emission properties in the visible region and a detection limit $\sim 42 \mathrm{ppb}$.

Polymeric materials with chromophore or flurophores have also garnered interest because of their potential applications. In $2005 \mathrm{Kim}$ and co-workers reported a structurally simple polymer that was sensitive for lead in aqueous environments. ${ }^{103}$ In the presence of lead, the polymer fluorescence is quenched. More recently, a polydiacetylenes (PDAs) were reported for lead sensing. ${ }^{104}$ In the presence of lead the polymers displayed a selective colorimetric change and a significant fluorescence enhancement. PDAs have an intense blue color and when in the presence of lead a transition to a bright pink occurs, a change in color that can be easily seen with the naked eye. ${ }^{104}$

\section{Concluding remarks}

Lead, has been a major threat to human and environmental health and it continues to be a persistent problem, though its industrial usage has decreased drastically. Several countries are dealing with outbreaks of lead poisoning while others are dealing with high levels of lead in their water systems. New findings highlight the detrimental effect of lead even at a very low concentration. In order to better manage these problems new techniques for detection have been developed, and or modifications to more established techniques have been made, which also helps in understanding its mechanism of action.

Selection of the best probe is based on the testing environment and purpose. Detection limit of probe and necessary sensitivity, state of sample (solution, solid, biological, etc.), testing environment (access to laboratory or on-site testing), and information desired (real-time imaging, concentration, or simple detection) all must be considered when selecting a probe. Electrochemical techniques have been extensively used but with the development of new probes (DNA, organic, and Bismuth based) this method has become safer, easier, and significantly more accurate. Electrochemical probes are easily used in the analysis of aqueous samples and with the development of portable electronics electrochemical probes can now be applied to on-site testing. Among various detection techniques optical detection appear to be the most convenient methods due simplicity and detection limits. Among these techniques fluorimetry is highly impressive for its high sensitivity, fast kinetics, and high spatial resolution among in situ application, real-time monitoring in both environmental and in vivo imaging. DNAzymes and nanoparticles have become a widely growing field for their unprecedented detection abilities, the combination of the two also can produce personalized sensors. DNAzymes are usually resistant to hydrolysis and allow for easy modification for the detection of a range of metal ions.

Organic molecules, especially fluorescent molecules, offer the necessary real-time and sensitivity desired for living specimen. These molecules can be modified for use in multiple solvents. Small molecules also have been synthesized with high selectively, great for mechanistic understanding of in vivo studies. Through the compilation of the some of the 
most promising techniques for the detection of $\mathrm{Pb}^{2+}$, it is concluded that customized sensors can be developed using many aspects (DNAzyme, nanoparticle, fluorescent, organic, electrochemical) depending are their intended usage. More generally the development of sophisticated detection methods can lead to a better understanding of $\mathrm{Pb}^{2+}$ toxicity, through the real-time monitoring of lead in organisms.

\section{Acknowledgments}

We appreciate helpful discussions with Ms. Lauren Marbella and Dr. Yi Lu. We thank the National Institutes of Health and Innovation Works for supporting our research.

\section{Acronyms}

CDC

BLLs

DBPs

EBLs

EPA

MCGL

FDA

CPSC

ICP-MS

ICP-AES

GFAAS

ASV

CSV

AdSV

MFE

HMDE

Bismuth film electrode

SPES

DPV

MMT

CPE

NP

DLS

AuNPs
Center of Disease Control

Blood lead levels

Disinfectant by-products

Elevated blood levels

Environmental Protection Agency

Maximum containment level goal

Food and Drug Administration

Consumer product safety commission

Inductively coupled plasma mass spectrometry

Inductively coupled plasma atomic emission spectrometry

Graphite furnance atomic adsorption spectroscopy

Anodic stripping voltammetry

Cathodic stripping voltammetry

Adsorptive stripping voltammetry

Mercury film electrode

Hanging mercury drop electrode

Screen-printed electrodes

Differential pulse voltammetry

Montmorillonite

Carbon paste electrode

Nanoparticles

Dynamic light scattering

Gold nanoparticles 


$\begin{array}{ll}\text { ssDNA } & \text { Single strand DNA } \\ \text { PVC } & \text { Polyvinyl chloride } \\ \text { PVC } & \text { Polydiacetylenes }\end{array}$

\section{References}

1. Galena. Missouri Department of Natural Resources, Division of Geology and Land Survey; 2006. Publication No. 000658

2. Cox, PA. Inorganic Chemistry in the Environment The Elements on Earth. Oxford: 1997.

3. Clune AL, Falk H, Riederer AM. Blacksmith Inst J Health Poll. 2011; 1

4. Mamtani R, Stern P, Dawood I, Cheema S. J Toxic. 2011; 2011 ID 319136.

5. CDC. MMWR. 1997; 46:141-146. [PubMed: 9072671]

6. Meyer P, Pivert T, Dignam T, Homa D, Schoonover J, Brody D. MMWR. 2003; 52

7. Lanphear BP, Dietrich K, Auinger P, Cox C. Public Health Rep. 2000; 115:521-529. [PubMed: 11354334]

8. Dietrich KN, Douglas RM, Succop PA, Berger OG, Bornschein RL. Neurotoxicol Teratol. 2001; 23:511-518. [PubMed: 11792521]

9. Braun JM, Kahn RS, Froehlich T, Auinger P, Lanphear BP. Environ Health Perspect. 2006; 114:1904-1909. [PubMed: 17185283]

10. Canfield RL, Henderson CR, Cory-Slechta DA, Cox C, Jusko TA, Lanphear BP. New Engl J Med. 2003; 348:1517-1526. [PubMed: 12700371]

11. Li J, Lu Y. J Am Chem Soc. 2000; 122:10466-10467.

12. Jain AK, Gupta VK, Singh LP, Raisoni JR. Electrochim Acta. 2006; 51:2547-2553.

13. Xiao Y, Rowe AA, Plaxco KW. J Am Chem Soc. 2006; 129:262-263. [PubMed: 17212391]

14. Zhang XB, Kong RM, Lu Y. Ann Rev Anal Chem. 2011; 4:105-128.

15. Oehme I, Wolfbeis OS. Microchimica Acta. 1997; 126:177-192.

16. Kim HN, Ren WX, Kim JS, Yoon J. Chem Soc Rev. 2011; 41:3013-3442.

17. Domaille DW, Que EL, Chang CJ. Nat Chem Bio. 2008; 4:168-175. [PubMed: 18277978]

18. Caroli, S. Chemical Analysis: Element Speciation in Bioinorganic Chemistry. Vol. 135. WileyInterscience Publication: John Wiley and Sons, Inc.; 1996.

19. Mateo, R. Watson, RT.; Fuller, M.; Pokras, M.; Hunt, WG., editors. Idaho, USA: The Peregrine Fund; 2009.

20. Sharma RK, Agrawal M. J Environ Biol. 2005; 26:301-313. [PubMed: 16334259]

21. Stanbury M, Rosenman K. Work-Related Health Disparities in Michigan. 2011

22. David JJ. J Urban Eco. 2012; 71:151-164.

23. Lin GZ, Peng PF, Chen Q, Wu ZG, Du L. Environ Res. 2009; 109:1-5. [PubMed: 18976991]

24. Mielke HW, Gonzales CR, Mielke PW Jr. Environ Res. 2011

25. Xie Y, Giammar DE. Water Res. 2011; 45:6525-6534. [PubMed: 22018527]

26. Smith P, Nriagu JO. Environ Res. 2011; 111:1, 81-86. [PubMed: 21112585]

27. Trejo-Acevedo A, Díaz-Barriga F, Carrizales L, Domínguez G, Costilla R. Chemosphere. 2009; 74:974-980. [PubMed: 19091374]

28. The Center for Disease Contol (U.S.). Preventing lead poisoning in young children: a statement [5th revision]. The Centers; Atlanta, GA: 2005.

29. Guney M, Zagury GJ. Envir Sci Tech. 2012; 48:4265-4274.

30. Weidenhamer JD, Clement ML. Chemosphere. 2007b; 69:1670-1672. [PubMed: 17631379]

31. Weidenhamer JD, Clement ML. Chemosphere. 2007c; 69:1111-1115. [PubMed: 17532022]

32. Morrison, WM. Health and Safety Concerns over U.S. Imports of Chinese Products: An Overview. RS22173. Congressional Research Service; 2009. 
33. http://service.mattel.com/us/recall.asp.

34. Lithner D, Damberg J, Dave G, Larsson A. Chemosphere. 2009; 74:1195-1200. [PubMed: 19108869]

35. Kawamura Y, Kawasaki C, Mine S, Mutsuga M, Tanamoto K. J Food Hyg Soc Jpn. 2006; 47:5157.

36. Weidenhamer JD, Clement ML. Chemosphere. 2007a; 67:961-965. [PubMed: 17166553]

37. Pirkle JL, Kaufman RB, Brody DJ, Hickman T, Gunter EW, Paschal DC. Environ Health Perspect. 1998; 106:745-750. [PubMed: 9799191]

38. Sedlak DL, von Gunten U. Science. 2011; 331:6013, 42.

39. Liu H, Korshin GV, Ferguson JF. Environ Sci Tech. 2009; 43:3278-3284.

40. Miranda M, Kim D, Hull A, Paul C, Galeano M. Envir Health Persp. 2007; 115

41. Edwards M, Dudi A. J Am Water Works Assoc. 2004; 96:69-81.

42. Edwards M, Triantafyllidou S, Best D. Environ Sci Technol. 2009; 43:1618-123. [PubMed: 19350944]

43. http://water.epa.gov/drink/contaminants/index.cfm

44. http://www.fda.gov/food/foodsafety/foodcontaminantsadulteration/metals/lead/ucm172050.htm $(05 / 14 / 2012)$

45. http://www.cpsc.gov/cpscpub/prerel/prhtml11/11278.html (05/14/2012)

46. Bannon DI, Murashchik C, Zapf CR, Farfel MR, Chisolm JJJ. Clin Chem. 1994; 40:1730-1734. [PubMed: 8070083]

47. Rabinowitz MB. Environ Health Perspect. 1991; 91:33-37. [PubMed: 2040248]

48. Bouton C, Frelin LP, Forde CE, Godwin HA, Pevsner J. J Neurochem. 2001; 76:1724-1735. [PubMed: 11259490]

49. Bressler J, Kim KA, Chakraborti T, Goldstein G. Neurochem Res. 1999; 24:595-600. [PubMed: 10227691]

50. Claudio ES, Godwin HA, Magyar JS. Prog Inorg Chem. 2003; 51:1-144.

51. Hanas JS, Rodgers JS, Bantle JA, Cheng YG. Mol Pharmacol. 1999; 56:982-988. [PubMed: 10531404]

52. Magyar JS, Weng TC, Stern TC, Dye CM, Rous DF, Payne BW, Bridgewater JC, Mijovilovich BM, Parkin A, Zaleski GJM, Penner-Hahn J, Godwin H. J Am Chem Soc. 2005; 127:9495-9505. [PubMed: 15984876]

53. Jin T, Lu J, Nordberg M. Neurotoxicology. 1998; 19:529-535. [PubMed: 9745907]

54. Sharma RK, Agrawal M. J Environ Bio. 2005; 26:301-313. [PubMed: 16334259]

55. Labbe RF, Vreman HJ, Stevenson DK. Clin Chem. 1999; 45:2060-2072. [PubMed: 10585337]

56. Bradman A, Eskenazi B, Sutton P, Athanasoulis M, Goldman LR. Environ Health Perspect. 2001; 109:1079-84. [PubMed: 11675273]

57. Hopkins MR, Ettinger AS, Hernandez-Avila M, Schwartz J, Tellez-Rojo MM, Lamadrid-Figueroa H, Bellinger D, Hu H, Wright RO. Environ Health Perspect. 2008; 116:1261-1266. [PubMed: 18795173]

58. Creed, JT.; Brockhoff, CA.; Martin, TD. Determination of trace elements in waters and wastes by inductively coupled plasma-mass spectrometry. EPA (U.S.); Cincinnati, OH: 1994. Revision 5.4

59. Martin, TD.; Brockhoff, CA.; Creed, JT.; Group, EMW. Determination of metals and trace elements in water and wastes by inductively coupled plasma-atmoic emission spectrometry. EPA (U.S.); Cincinnati, OH: 1994. Revision 4.4

60. Creed, JT.; Martin, TD.; O'Dell, JW. Determination of trace elements by stabilized temperature graphite furnace atomic absorption. EPA (U.S.); Cincinnati, OH: 1994. Revision 2.2

61. Hepp NM, Mindak WR, Cheng J. J Cosmetic Sci. 2009; 60:405-414.

62. CPSC. Testing Method: CPSC-CH-E1002-08. http://www.cpsc.gov/about/cpsia/CPSC-CHE1002-08.pdf (05/17/2012)

63. Bannon DI, Chisolm JJ. Clin Chem. 2001; 47:1703-1704. [PubMed: 11514407]

64. Yang WR, Chow E, Willett GD, Hibbert DB, Gooding JJ. Analyst. 2003; 128:712-718. [PubMed: 12866893] 
65. Baldo MA, Daniele S, Ciani I, Bragto C, Wang J. Electroanalysis. 2004; 16:360-366.

66. Copeland TR, Skogerboe RK. Anal Chem. 1974; 46:1257-1268.

67. Kefala G, Economou A, Voulgaropoulos A, Sofoniou M. Talanta. 2003; 61:603-610. [PubMed: 18969224]

68. Bannon DI, Murashchik C, Zapf CR, Farfel MR, Chisolm JJ. Clin Chem. 1994; 40:1730-1734. [PubMed: 8070083]

69. Quintana JC, Arduini F, Amine A, Punzo F, Destri GL, Bianchini C, Zane D, Curulli A, Palleschi G, Moscone D. Analytica Chimica Acta. 2011; 707:171-177. [PubMed: 22027135]

70. Li F, Feng Y, Zhao C, Tang B. Chem Comm. 2011; 47:11909-11911. [PubMed: 21975421]

71. Liu M, Zhao G, Tang Y, Yu Z, Lei Y, Li M, Zhang Y, Li D. Environ Sci Tech. 2010; 44:42414246.

72. Bouw RGB, Tonl IK, Letaief S, Ngameni E, Detellier C. Applied Clay Sci. 2011; 52:258-265.

73. Abbaspour A, Mirahmadi E, Khalafi-Nejad A, Babamohammadi S. J Haz Mat. 2010; 174:656661.

74. Yang J, Zhou C, Liu C, Li Y, Liu H, Zhu D. Analyst. 2012; 137:1446-1450. [PubMed: 22311275] 75. Wang X, Guo X. Analyst. 2009; 134:1348-1354. [PubMed: 19562200]

76. Breaker RR, Joyce GF. Chem Biol. 1994; 1:223-229. [PubMed: 9383394]

77. Liu J, Lu Y. J Am Chem Soc. 2003; 125:642-6643. [PubMed: 12526658]

78. Lan T, Furuya K, Lu Y. Chem Comm. 2010; 46:3896-3898. [PubMed: 20407665]

79. Wen Y, Peng C, Li D, Zhuo L, He S, Wang L, Huang Q, Xu QH, Fan C. Chem Comm. 2011; 47:6278-6280. [PubMed: 21503363]

80. Chang IH, Tulock JJ, Liu J, Kim WS, Cannon DM Jr, Lu Y, Bohn PW, Sweedler JV, Cropek DM. Envir Sci Tech. 2005; 39:3756-3761.

81. Wang H, Ou LML, Suo Y, Yu HZ. Anal Chem. 2011; 83:1557-1563. [PubMed: 21309534]

82. Chen X, Guan H, He Z, Zhou X, Hu J. Anal Meth. 2012; 4:1619-1622.

83. Berne BJ, Pecora R. Bio Phy Dover. 2000

84. Pecora R. J Nanopart Res. 2000; 2:123-131.

85. Miao X, Ling L, Shuai X. Anal Biochem. 2012; 421:582-586. [PubMed: 22197417]

86. Miao X, Ling L, Shuai X. Chem Comm. 2011; 47:4192-4194. [PubMed: 21369573]

87. Chang MY, Pralle A, Isacoff EY, Chang CJ. J Am Chem Soc. 2008; 126:15392-15393. [PubMed: 15563161]

88. Gabe Y, Urano Y, Kikuchi K, Kojima H, Nagano T. J Am Chem Soc. 2008; 126:3357-3367. [PubMed: 15012166]

89. Griffin BA, Adams SR, Tsien RY. Science. 1998; 281:269-272. [PubMed: 9657724]

90. Haugland, RP. Molecular Probes, Inc.; Eugene, Oregon: 2002. p. 55-767.

91. Lim MH, Xu D, Lippard SJ. Nat Chem Bio. 2006; 2:375-380. [PubMed: 16732295]

92. Miller EW, Tulyathan O, Isacoff EY, Chang CJ. Nat Chem Bio. 2007; 3:263-267. [PubMed: 17401379]

93. Rosania GR, Lee JW, Ding L, Yoon HS, Chang YT. J Am Chem Soc. 2003; 125:1130-1131. [PubMed: 12553790]

94. Geddes, CD.; Lakowicz, JR. Springer Verlag; 2005.

95. Tour O, Adams SR, Kerr RA, Meijer RM, Sejnowski TJ, Tsien RW, Tsien RY. Nat Chem Bio. 2007; 3:423-431. [PubMed: 17572670]

96. Chen CT, Huang WP. J Am Chem Soc. 2002; 124:6246-6247. [PubMed: 12033846]

97. He Q, Miller EW, Wong AP, Chang CJ. J Am Chem Soc. 2006; 128:9316-9317. [PubMed: 16848451]

98. Ranyuk E, Douaihy CM, Bessmertnykh A, Denat F, Averin A, Beletskaya I, Guilard R. Org Let. 2009; 11:987-990. [PubMed: 19199769]

99. Askunar N. Sensors Actuators B: Chem. 2011; 157:162-168.

100. Marbella L, Serli-Mitasev B, Basu P. Angew Chem Int Ed. 2009; 48:3996-3998. 
101. Zhao L, Wu T, Lefevre JP, Leray I, Delaire JA. Lab on a Chip. 2009; 9:2818. [PubMed: 19967119]

102. Faye D, Lefevre JP, Delaire JA, Leray I. J Photochem Photobio A: Chem. 2012; 234:115-122.

103. Kim IB, Dunkjorst A, Gilbert J, Bunz UHF. Macromolecules. 2005; 38:4560-4562.

104. Lee KM, Chen X, Fang W, Kim JM, Yoon J. Macromol Rapid Comm. 2011; 32:497-500.

105. Hou C, Xiong Y, Fu N, Jacquot CC, Squier TC, Cao H. Tetra Let. 2011; 52:2692-2696.

106. Shamsipur M, Sadeghi M, Alizadeh K, Bencini A, Valtancoli B, Garau A, Lippolis V. Talanta. 2010; 80:2023-2033. [PubMed: 20152448]

107. Yanaz Z, Filik H, Apak R. Sensors Actuators B: Chem. 2010; 147:15-22.

108. Bualom C, Ngeontae W, Nitiyanontakit S, Ngamukot P, Imyim A, Tuntulani T, Aeungmaitrepirom W. Talanta. 2010; 82:660-667. [PubMed: 20602951]

109. Son H, Lee HY, Lim JM, Kang D, Han WS, Lee SS, Jung JH. Chem-A Euro J. 2010; 16:11549_ 11553.

110. Wang JJ, Wang XJ, Geng Y, Tung CH, Wi LZ. Sci China Series B: Chem. 2009; 52:765-770. 


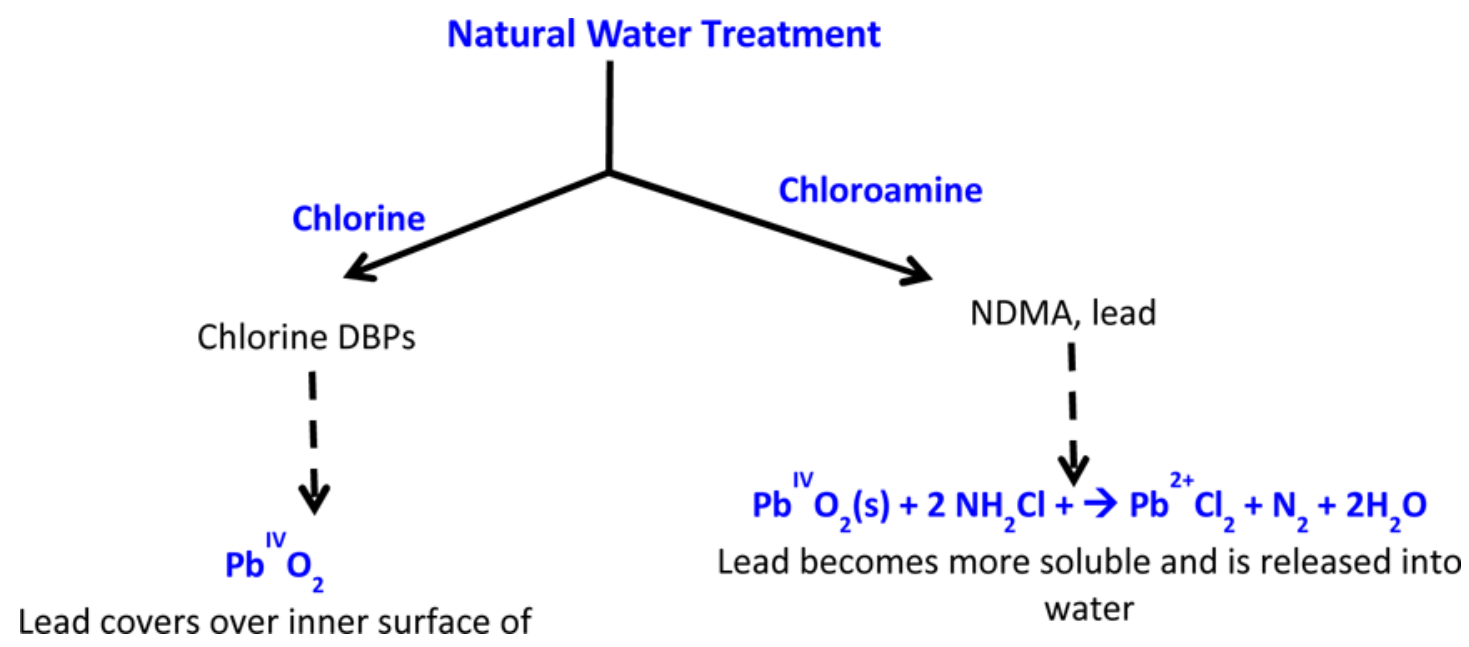

Figure 1.

A schematic of purification processes for drinking water. Chlorination generates chlorine disinfection by-products (DBPs) but oxidizes lead to a slightly insoluble $\mathrm{Pb}^{4+}$ state.

Chloramine causes increased release of lead from plumbing, it is a weaker oxidant that does not oxidize $\mathrm{Pb}^{2+}$ to $\mathrm{Pb}^{4+}$ 


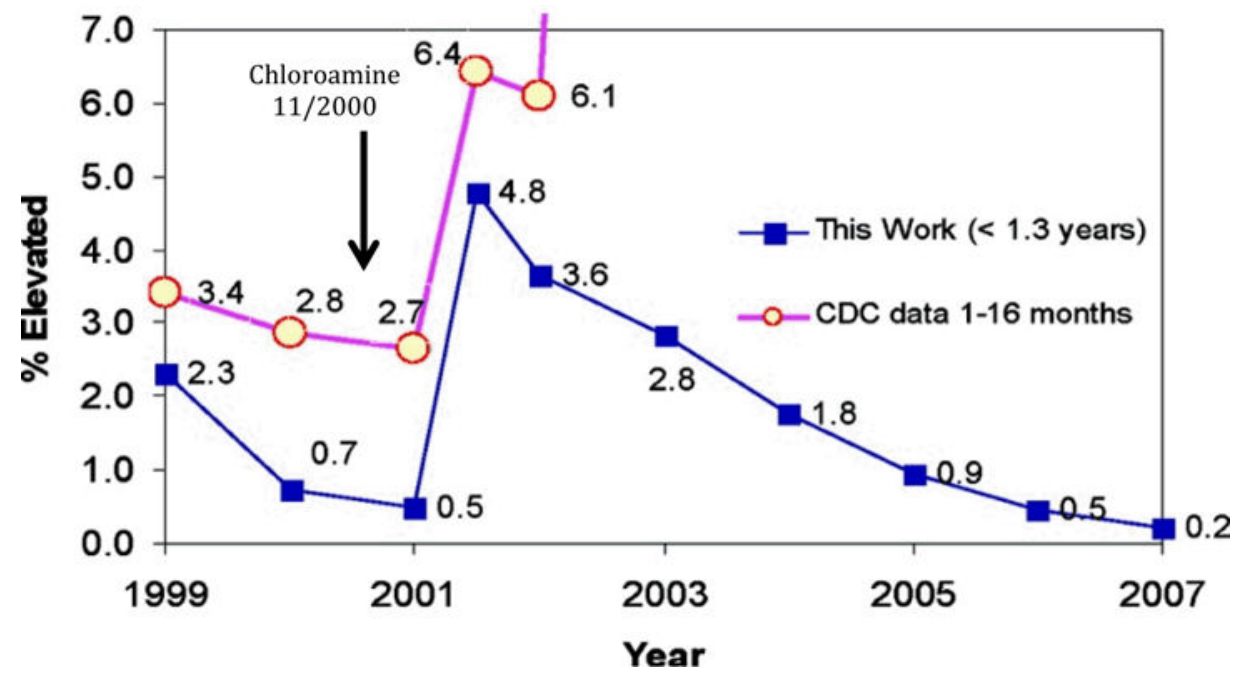

Figure 2.

Trends in elevated blood lead levels (EBL) incidence for children aged $\unlhd .3$ years taken from reference ${ }^{40}$ with permission. 


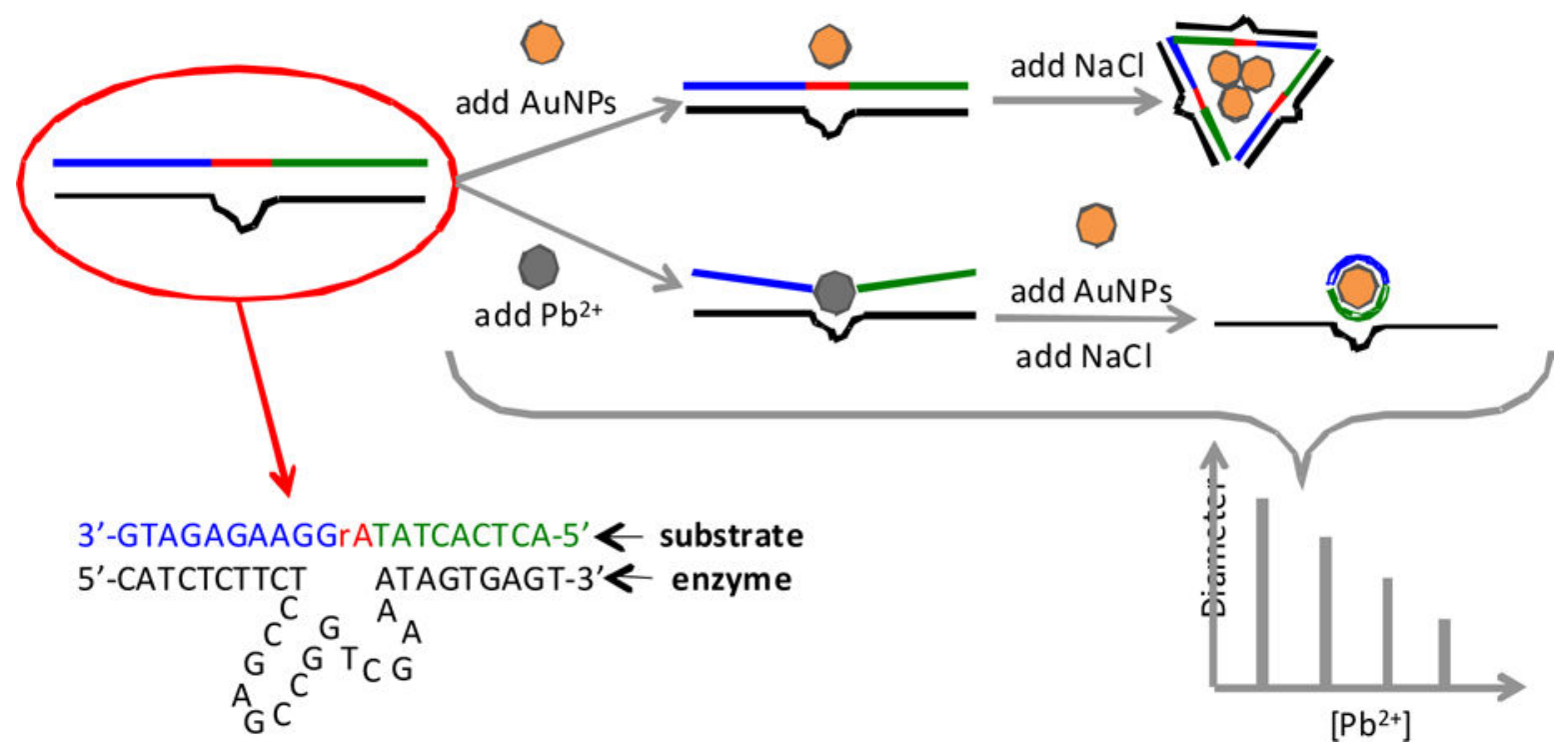

Figure 3.

Schematic illustration of $\mathrm{Pb}^{2+}$ detection using DLS. ${ }^{85,86}$ 


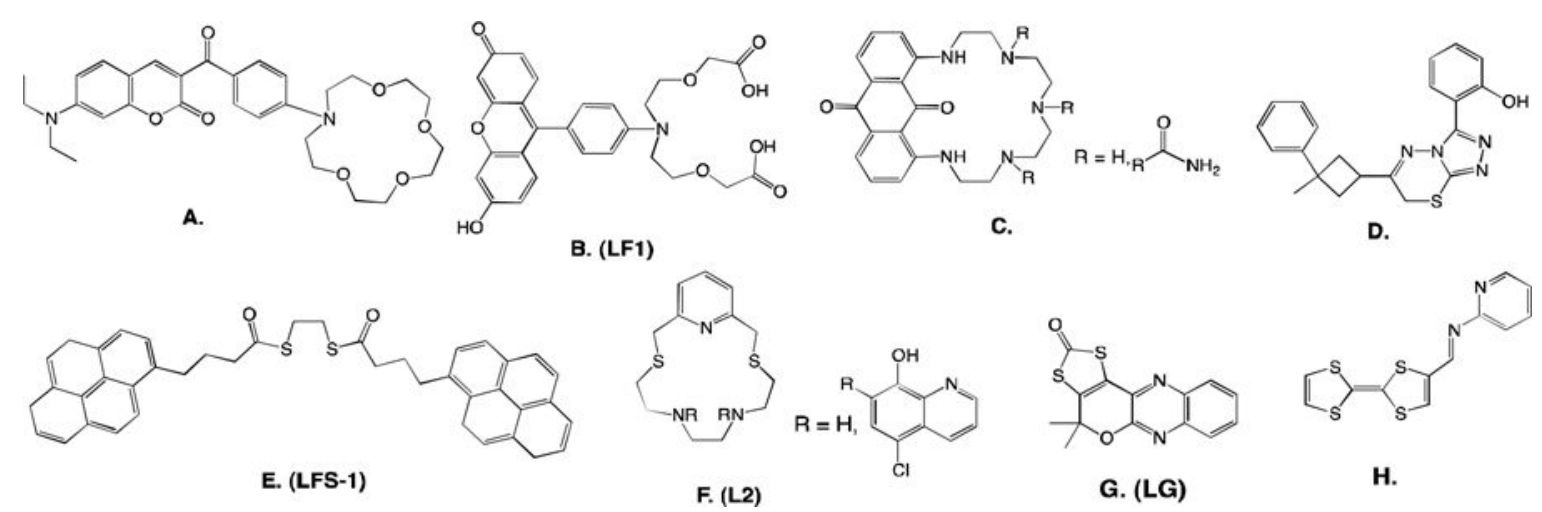

Figure 4.

Small organic lead sensors. A.) Ketoaminocoumarin ${ }^{96}$ B.) Leadfluor-1, LF1 ${ }^{97}$ C.) $1,8-$ diaminoanthraquinone ${ }^{98}$ D.) Triazolo-thiadiazi, imbedded in $\mathrm{PVC}^{99} \mathrm{E}$.) Lead fluorescent sensor, LFS-1 ${ }^{104}$ F.) 5,8-bis((5'-chloro-8'-hydroxy-7'-quinolinyl)methyl)-2,11-dithia-5,8diaza-2,6-pyridinophane, L2, imboilized in $\mathrm{PVC}^{105}$ G.) Leadglow, LG ${ }^{100} \mathrm{H}$.) Imine-bridged TTF-pi-pyridine derivative ${ }^{109}$ 


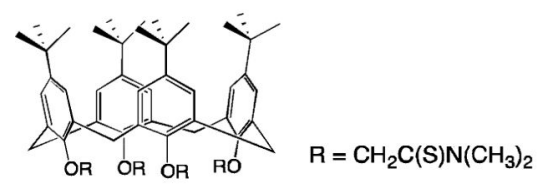

A.
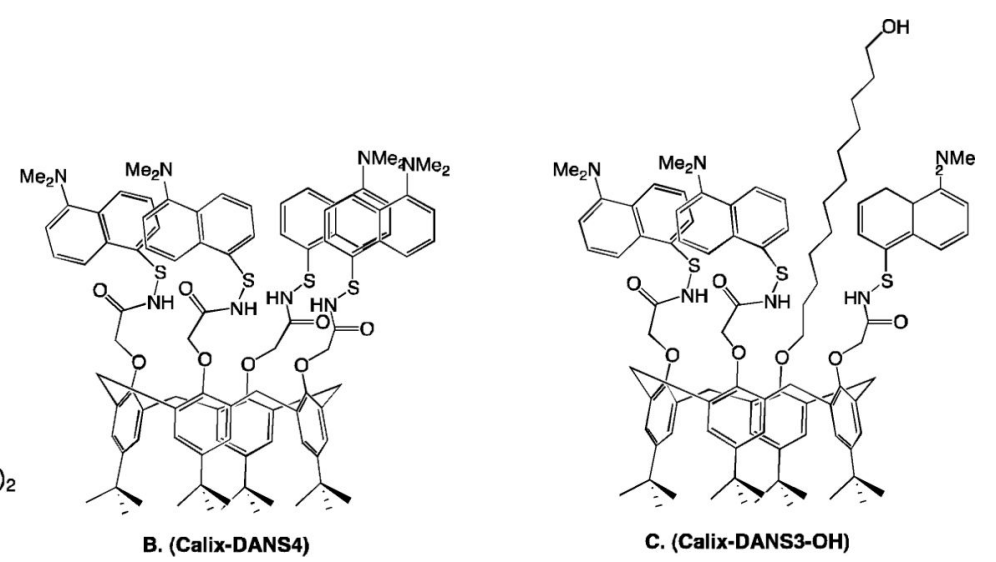

Figure 5.

Macro-organic lead sensors. A.) Ionophore imbedded in $\mathrm{PVC}^{107}$ B.) Calix-DANS4 ${ }^{101}$ C.) Calix-DANS3-OH incorporated into a PDMS microfluidic chip ${ }^{102}$ 


\section{Table 1}

List of Standardized Lead Levels.

\begin{tabular}{|c|c|c|c|}
\hline & Agency & Focus & MCL \\
\hline \multirow{5}{*}{ United States } & \multirow{2}{*}{ EPA } & Drinking Water & $15 \mathrm{ppb}$ \\
\hline & & Air & $1.5 \mu \mathrm{g} / \mathrm{m}^{3}$ \\
\hline & \multirow{2}{*}{ CPSC } & Children's Toys ( 12 or younger) & $100 \mathrm{ppm}$ \\
\hline & & Paint & $600 \mathrm{ppm}$ reduced to $90 \mathrm{ppm}$ \\
\hline & FDA & Food and Dishware & $0.5-7.0 \mathrm{ppm}$ leaching solution \\
\hline \multirow{3}{*}{ Canada } & \multirow{3}{*}{$\begin{array}{l}\text { Health } \\
\text { Canada }\end{array}$} & Drinking Water & $10 \mathrm{ppb}$ \\
\hline & & Air & N/A \\
\hline & & Children's Toys (12 or younger) & $90 \mathrm{ppm}$ \\
\hline \multirow{3}{*}{$\mathrm{EU}$} & \multirow{3}{*}{$\begin{array}{c}\text { European } \\
\text { Commission }\end{array}$} & Drinking Water & $10 \mathrm{ppb}$ \\
\hline & & Air & $0.5 \mu \mathrm{g} / \mathrm{m}^{3}$ \\
\hline & & Children's Toys ( 12 or younger) & N/A \\
\hline International & WHO & Drinking water & $10 \mathrm{ppb}$ \\
\hline
\end{tabular}




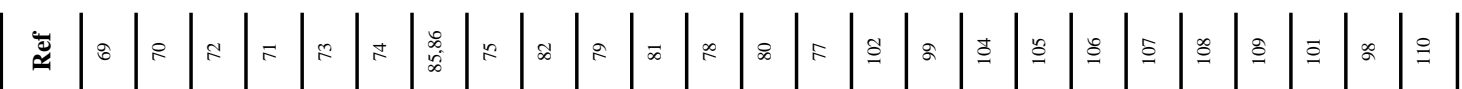

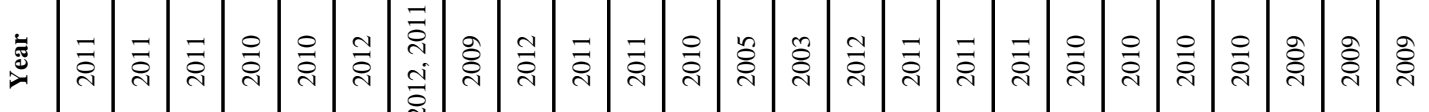

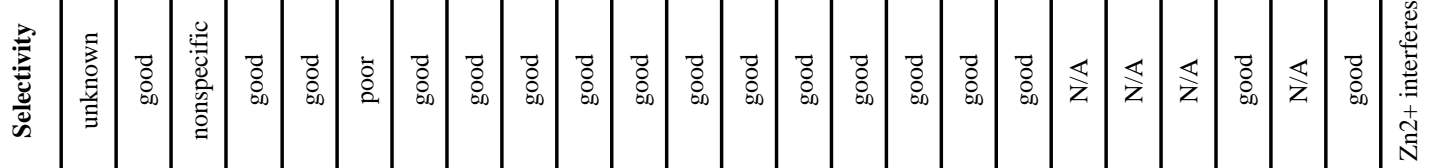

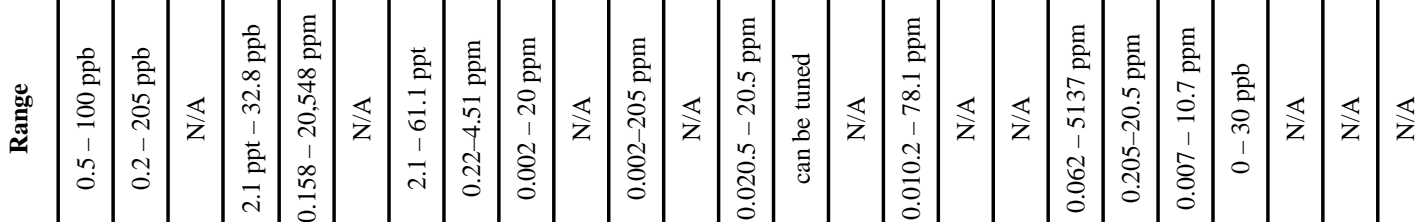

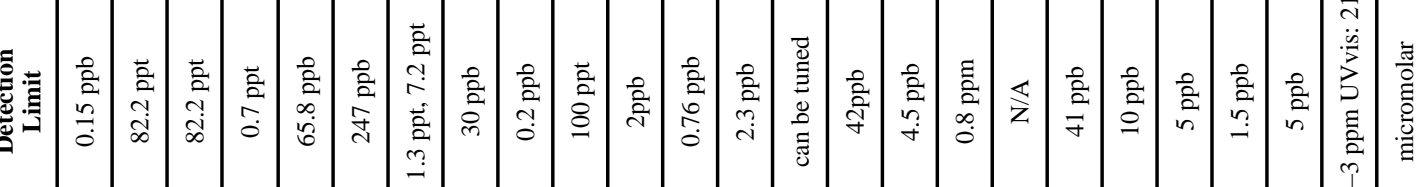

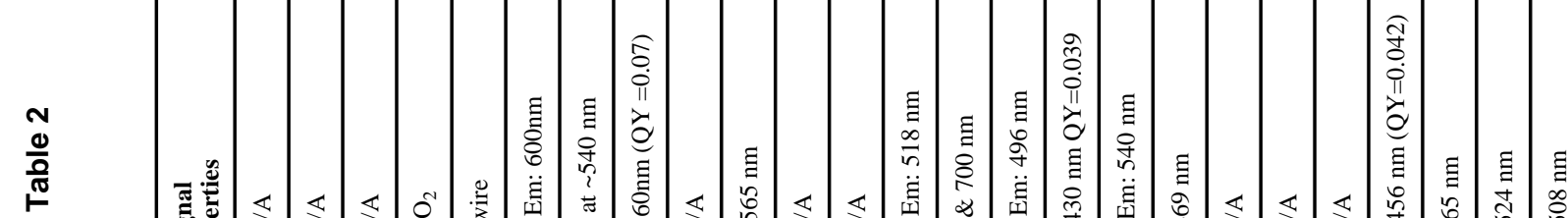

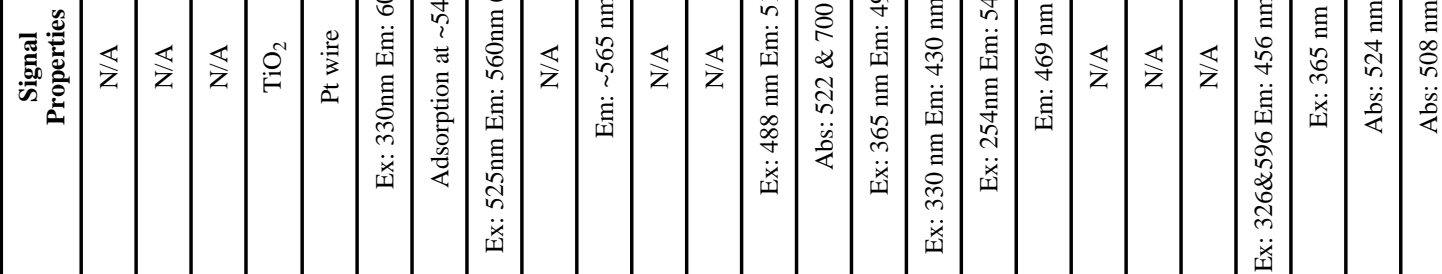

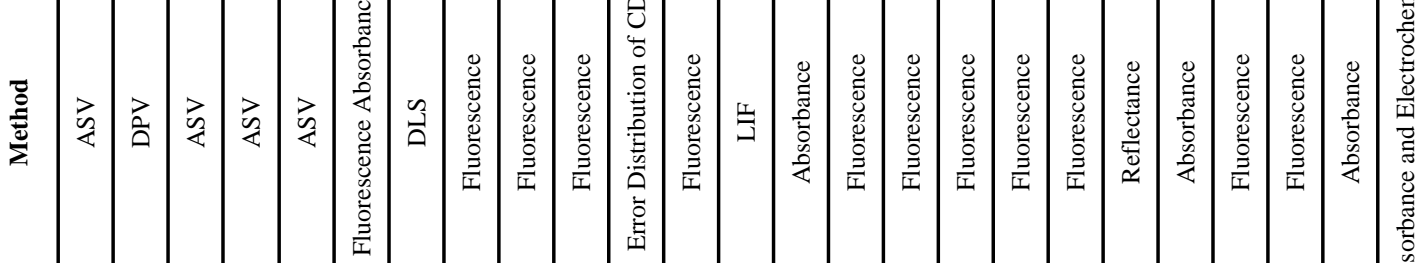

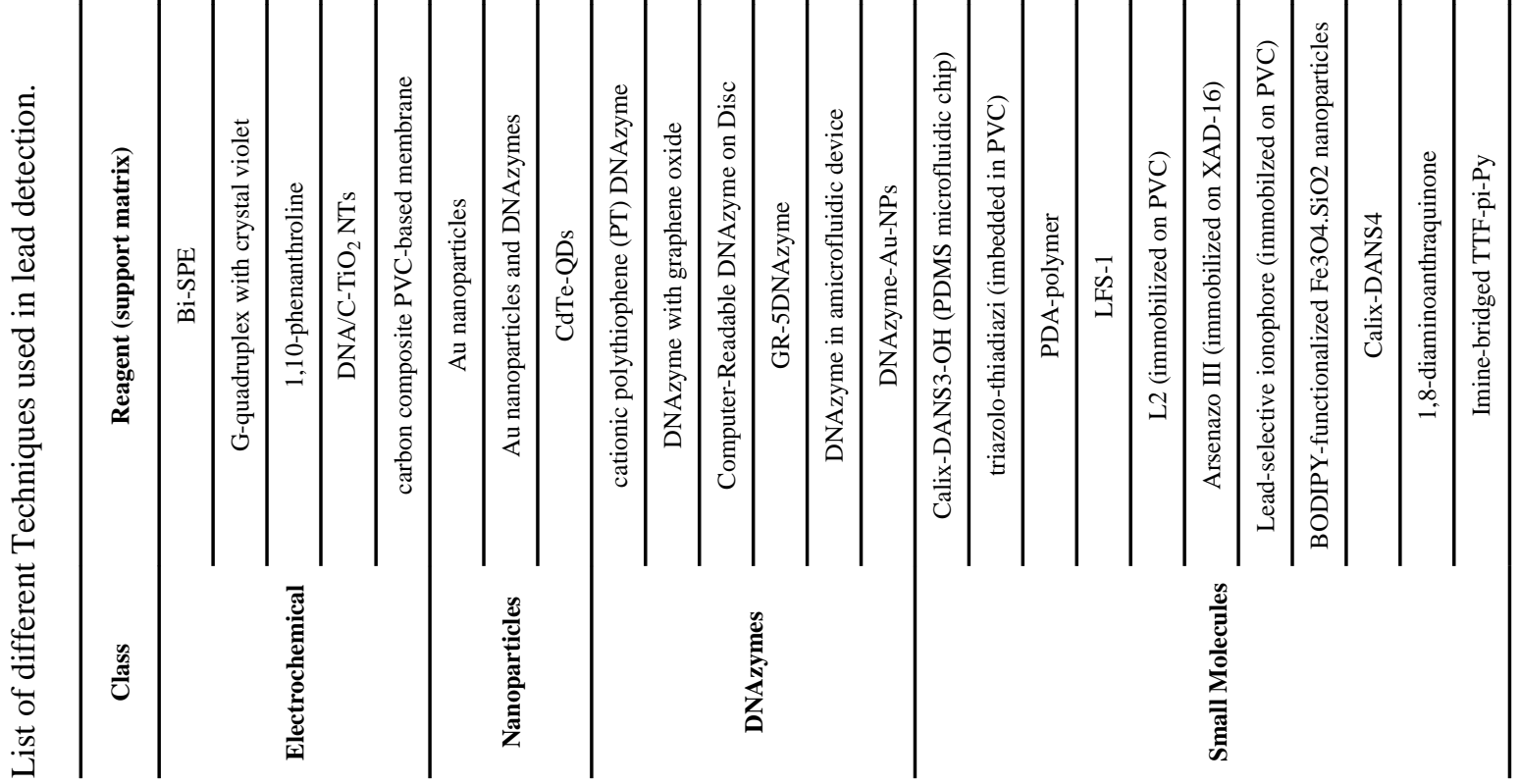


